\title{
IMPACTS OF CLIMATE CHANGE SCENARIOS IN THE BRAZILIAN SEMIARID REGION ON WATERMELON CULTIVARS ${ }^{1}$
}

\author{
TALYANA KADJA DE MELO², JOSÉ ESPÍNOLA SOBRINHO², JOSÉ FRANSCIMAR DE MEDEIROS ${ }^{2}$, VLADIMIR \\ BATISTA FIGUEIREDO ${ }^{2}$, JOSÉ SILEREUDO DA SILVA², FRANCISCO VANIES DA SILVA SÁ2*
}

\begin{abstract}
The phenology and water demand of crops can be altered by climate change. The objective of this study was to evaluate the impacts of climate change (temperature and relative humidity) on the development and evapotranspiration (ETc) of watermelon cultivars (Citrullus lanatus Schrad) in irrigated plantations in the Brazilian semiarid region. The experiments were conducted at the Rafael Fernandes Experimental Farm, in the municipality of Mossoró, RN, Brazil. The first experiment was carried out from February to April 2006, evaluating the cultivar Mickylee. In the second experiment, carried out from September to November 2009, the cultivar Quetzali was used. Two climate change scenarios were evaluated based on the Intergovernmental Panel on Climate Change (IPCC) report: an optimistic one named B2 and a pessimistic one named A2. It was found that climate change may cause reductions in crop vegetative cycle of 14.1 and $26.9 \%$ for the cultivar Mickylee and 7.9 and $11.1 \%$ for the cultivar Quetzali, for the optimistic and pessimistic scenarios, respectively, compared to the current climate scenario. Future climate changes will increase the watermelon crop coefficient (Kc), for the conditions under which the present study was carried out, increasing the daily ETc the total ETc, mainly for the cultivar Mickylee. Future climate changes in air temperature and relative humidity will reach limits above those tolerated by the crop, which will lead to changes in the cultural practices and irrigation management.
\end{abstract}

Keywords: Citrullus lanatus. Temperature. Relative Humidity. Evapotranspiration. Phenology.

\section{IMPACTOS DOS CENÁRIOS DE MUDANÇAS CLIMÁTICAS NO SEMIÁRIDO BRASILEIRO SOB CULTIVARES DE MELANCIEIRA}

RESUMO - A fenologia e a demanda hídrica das culturas podem ser alteradas pelas mudanças climáticas. Com isso, objetivou-se com o presente trabalho avaliar os impactos das mudanças climáticas (temperatura e umidade relativa do ar) sobre o desenvolvimento e a evapotranspiração (ETc) de cultivares de melancieira (Citrullus lanatus Schrad) em cultivo irrigado no semiárido brasileiro. Os experimentos foram conduzidos na Fazenda Experimental Rafael Fernandes, no município de Mossoró, RN, Brasil. O primeiro experimento foi realizado no período de fevereiro a abril de 2006, avaliando a cultivar "Mickylee". No segundo experimento, realizado de setembro a novembro de 2009, utilizou-se a cultivar "Quetzali". Foram avaliados dois cenários de mudanças climáticas baseados no relatório do Intergovernmental Panel on Climate Change (IPCC): um otimista denominado B2 e um pessimista denominado A2. Verificou-se que as mudanças climáticas poderão provocar redução no ciclo vegetativo da cultura de 14,1 e 26,9\% para a cultivar "Mickylee" e de 7,9 e 11,1\% para a cultivar "Quetzali", isso para os cenários otimista e pessimista, respectivamente, em relação ao cenário climático atual. As mudanças climáticas futuras aumentarão o coeficiente de cultivo $(\mathrm{Kc})$ da melancieira, nas condições em que o presente estudo foi realizado, incrementando a ETc diária, e aumento da ETc total, principalmente da cultivar "Mickylee". As mudanças climáticas futuras na temperatura e umidade relativa do ar, atingirão limites acima dos tolerados pela cultura, fato que acarretará em mudanças nos tratos culturais e no manejo da irrigação.

Palavras-chave: Citrullus lanatus. Temperatura. Umidade relativa. Evapotranspiração. Fenologia.

\footnotetext{
${ }^{*}$ Corresponding author

${ }^{1}$ Received for publication in $11 / 20 / 2019$; accepted in $05 / 22 / 2020$.

Paper extracted from the doctoral thesis of the first author.

${ }^{2}$ Center of Agrarian Sciences, Universidade Federal Rural do Semi-Árido - UFERSA, Mossoró, RN, Brazil; talyanakadja@hotmail.com ORCID: 0000-0003-3730-9071, jespinola@ufersa.edu.br - ORCID: 0000-0002-4953-245X,jfmedeir@ufersa.edu.br - ORCID: 0000-0003 -1202-8783, vladimir@ufersa.edu.br - ORCID: 0000-0002-0019-7937, silereudo.silva@ifrn.edu.br - ORCID: 0000-0003-1519-6555, vanies_agronomia@hotmail.com-ORCID: 0000-0001-6585-8161.
} 


\section{INTRODUCTION}

The impacts of climate change on food security represent important challenges for the world population and directly involve the agricultural sector (KASTNER et al., 2012; NELSON et al., 2014). The Intergovernmental Panel on Climate Change (IPCC) points out that the negative impacts of climate change on agricultural production are already being observed in different regions of the planet, such as reduced crop yield.

This fact raises concerns, since the demand for food tends to increase by $2 \%$ in the next decades, especially in developing countries, due to the expectation of population growth and improvement in the economic conditions of several countries (SCHEMBERGUE et al., 2017). However, the search for increasing food production makes this scenario a worrying one, since the growth of the agricultural sector contributes to intensifying the emissions of greenhouse gases (GHGs) (BEDDINGTON et al., 2012).

In the Brazilian semiarid region, identifying changes in hydrological cycle becomes relevant due to the intense temporal and spatial variability of rainfall (SCHMIDT; LIMA; JESUS, 2018). In future scenarios of climatic conditions, ETo is one of the most affected variables of the hydrological cycle, since changes in this variable due to alterations in temperature and relative humidity have negative impacts on the vegetative cycle duration and yield of crops (CAVALCANTE JÚNIOR et al., 2018). Thus, the use of computer models to simulate the responses of the main agricultural crops in the face of future climate change scenarios enables planning and decision-making management in the agricultural sector, saving time, work and amount of resources (SILVA; SILVA; AZEVEDO, 2012).

Watermelon (Citrullus lanatus Schrad) belongs to the Cucurbitaceae family, and its center of origin is tropical Africa. It is a fruit vegetable cultivated in various regions of the world and throughout the Brazilian territory, mainly in the semiarid northeast region (COSTA et al., 2012; CHAVES; FERREIRA; ALVES, 2013). The Brazilian semiarid region stands out for being a major producer of watermelon, but the drought periods directly affect the production of the crop, since rains are the main source of water used by small and medium producers (NUNES et al., 2017). However, irrigated watermelon cultivation has grown in several northeastern states, such as Rio Grande do Norte and Bahia, using cultivars with small fruits, hence with characteristics suitable for export.

The yield of a species or cultivar can be directly influenced by the edaphoclimatic conditions to which it was subjected (CARMO et al., 2015). Such variability of responses, within the same variety or genotype, when grown in different production systems (edaphoclimatic conditions), is related to the environmental factor together with the genetic component, acting on physiological and morphological responses of the plant (DALASTRA; ECHER; HACHMANN, 2015).

The objective of this study was to evaluate the future impacts of climate change (temperature and relative humidity) on the development and evapotranspiration of watermelon cultivars: Mickylee and Quetzali, in irrigated cultivation in the Brazilian semiarid region.

\section{MATERIAL AND METHODS}

Data of crop coefficients $(\mathrm{Kc})$, as well as climatic variables (air temperature, relative humidity, wind speed, global radiation and precipitation), were obtained from experiments installed in the municipality of Mossoró, State of Rio Grande do Norte (FIGUEIRÊDO et al., 2009; COSTA et al., 2013). According to Köppen's classification, the climate of the municipality is classified as BSh, that is, dry semiarid climate (ALVARES et al., 2014). According to Diniz and Pereira (2015), the average temperature of the region is $27.4{ }^{\circ} \mathrm{C}$, with average relative humidity of $68.9 \%$, very irregular annual rainfall, with an average of $673.9 \mathrm{~mm}$ and a drought period of 6 to 8 months.

The experiments were conducted at the Rafael Fernandes Experimental Farm, which belongs to the Federal Rural University of the Semi-Arid Region UFERSA (latitude: $5^{\circ} 03$ ' 37' S; longitude: $37^{\circ} 23$ ' 50 " W; and altitude of $72 \mathrm{~m}$ ). The soil of the area was classified as Argissolo Vermelho-Amarelo distrófico latossólico (Ultisol), according to the Brazilian Soil Classification System (EMBRAPA, 1999).

The first experiment was carried out from February to April 2006, evaluating the watermelon cultivar Mickylee. This cultivar has cycle of around 60 to 80 days, small fruits ( 5 to $7 \mathrm{~kg}$ ) with round shape, light green rind with dark green reticulated pattern and reddish flesh. The spacing used was $2.0 \mathrm{x}$ 0.4 meters between rows and plants, respectively, totaling 12,500 plants per hectare. The crop cycle lasted 78 days (FIGUEIRÊDO et al., 2009).

The second experiment was carried out from September to November 2009, using the watermelon cultivar Quetzali, which is an early variety, with a cycle of 60 to 70 days, small fruits $(2.5$ to $6.0 \mathrm{~kg})$ with round shape, green rind with dark and thin striations, and red flesh with few seeds. The spacing was $2.0 \times 0.5 \mathrm{~m}$ between rows and plants, respectively, totaling 10,000 plants per hectare. The crop was grown on mulch (black-white polyethylene film, with the white side facing upwards). The crop cycle lasted 63 days, counted from the transplanting (COSTA et al., 2013).

The area was irrigated by a localized drip 
irrigation system, with one lateral line per row of plants and emitters with flow rates of 1.65 and $1.3 \mathrm{~L} \mathrm{~h}^{-1}$ for experiments 1 and 2, respectively, operating at a $100 \mathrm{kPa}$ pressure per dripper.

The determination of ETc, in the different stages, was performed by means of weighing lysimeters, with dimensions of $1.5 \times 1.8 \mathrm{~m}$ (area of 2.70 $\mathrm{m}^{2}$ ) and $0.9 \mathrm{~m}$ depth. Each lysimeter was positioned on a precision electronic scale, connected to a sensitive element (load cell), coupled to a data acquisition system (datalogger - CR23X model, Campbel Scientific brand). ETc was determined using the methodology recommended by Silva, Folegatti and Nova (2005), in which all lysimeter readings were analyzed daily so that occurrences of rainfall, irrigation or drainage from the soil volume were identified and disregarded in ETc calculation. Once this daily procedure was performed, the mass was obtained by converting the electrical signal using the calibration equation and the evapotranspired water depth obtained by the relationship between the mass and the area occupied by the plants in the lysimeter $(1.6 \times 2.0 \mathrm{~m})$.

For calculation of the average Kc values, the crop cycle was divided into four phenological stages, defined according to Allen et al. (2006), as follows: I) initial stage: from planting up to $10 \%$ of soil cover; II) growth stage: from the end of the initial stage up to $80 \%$ of soil cover; III) intermediate stage: from the establishment of total soil cover to the beginning of maturation; and IV) final stage: from the end of stage III until harvest.

Reference evapotranspiration (ETo) was estimated by the Penman-Monteith method parameterized by FAO (ALLEN et al., 2006) (Equation $1)$. The meteorological data required to determine the ETo (mean, maximum and minimum temperatures; maximum and minimum relative air humidity; wind speed and global radiation) were obtained from an automatic weather station installed in the experimental areas.

$$
E T o=\frac{0.408 \Delta(R n-G)+\gamma \frac{900}{T_{\text {mean }}+273} u_{2}\left(e_{s}-e_{a}\right)}{\Delta+\gamma\left(1+0.34 u_{2}\right)}
$$

Where: ETo - reference evapotranspiration, $\mathrm{mm}^{\mathrm{day}}{ }^{-}$ ${ }^{1} ; \Delta$ - slope of the saturation vapor pressure curve, $\mathrm{kPa}{ }^{\circ} \mathrm{C}^{-1} ; \gamma$ - psychrometric constant, $\mathrm{kPa}{ }^{\circ} \mathrm{C}^{-1} ; \mathrm{Rn}-$ net radiation, $\mathrm{MJ} \mathrm{m}^{-2}$ day $^{-1} ; \mathrm{G}$ - soil heat flux, $\mathrm{MJ} \mathrm{m}^{-2}$ day $^{-1} ; \mathrm{T}_{\text {mean }}-$ mean daily air temperature at $2 \mathrm{~m}$ height, ${ }^{\circ} \mathrm{C} ; \mathrm{U}_{2}$ - wind speed at $2 \mathrm{~m}$ height, $\mathrm{m} \mathrm{s}^{-1} ; \mathrm{e}_{\mathrm{a}}$ actual water vapor pressure, $\mathrm{kPa}$; and $\mathrm{e}_{\mathrm{S}}$ - saturation water vapor pressure, $\mathrm{kPa}$.

Accumulated degree days (ADD) was determined using the methodology of Ometto (1981), which according to Renato et al. (2013) is the most indicated for the simulations, especially in climate change scenarios that project greater increments in air temperature, because this methodology uses the upper and lower basal temperatures and considers a higher penalty on days when the maximum temperature exceeds the upper basal temperature. In this method the thermal sum has five constraints, each with a specific equation for calculating DD (Equations 2, 3, 4, 5 and 6):

1) $\mathrm{TB}>\mathrm{TM}>\mathrm{Tm}>\mathrm{Tb}$
$\mathrm{DD}=\frac{\mathrm{TM}-\mathrm{Tm}}{2}+\mathrm{Tm}-\mathrm{Tb}$

2) $\mathrm{TB}>\mathrm{TM}>\mathrm{Tb}>\mathrm{Tm}$

$\mathrm{DD}=\frac{(\mathrm{TM}-\mathrm{Tm})^{2}}{2(\mathrm{TM}-\mathrm{Tm})}$

3) $\mathrm{TB}>\mathrm{Tb}>\mathrm{TM}>\mathrm{Tm}$

$\mathrm{DD}=0$

4) $\mathrm{TM}>\mathrm{TB}>\mathrm{Tm}>\mathrm{Tb}$

$\mathrm{DD}=\frac{2(\mathrm{TM}-\mathrm{Tm})(\mathrm{Tm}-\mathrm{Tb})+(\mathrm{TM}-\mathrm{Tm})^{2}-(\mathrm{TM}-\mathrm{TB})}{2(\mathrm{TM}-\mathrm{Tm})}$

5) $\mathrm{TM}>\mathrm{TB}>\mathrm{Tb}>\mathrm{Tm}$

$\mathrm{DD}=\frac{1}{2} \cdot \frac{(\mathrm{TM}-\mathrm{Tb})^{2}-(\mathrm{TM}-\mathrm{TB})^{2}}{\mathrm{TM}-\mathrm{Tm}}$

where: DD - degree days, ${ }^{\circ} \mathrm{C}$; TM - maximum temperature of the day, ${ }^{\circ} \mathrm{C}$; $\mathrm{Tm}$ - minimum temperature of the day, ${ }^{\circ} \mathrm{C} ; \mathrm{Tb}$ - lower basal temperature, ${ }^{\circ} \mathrm{C}$; and TB - upper basal temperature, ${ }^{\circ} \mathrm{C}$. The lower basal temperature used in the model for watermelon crop was $11{ }^{\circ} \mathrm{C}$ and the upper basal temperature was $35^{\circ} \mathrm{C}$ (REZENDE; DIAS; COSTA, 2010).

To verify the influence of climate change on water consumption and crop development, changes in air temperature and relative humidity expected for the year 2100 were simulated. In the simulations, the other climatic variables (wind speed and global solar radiation) remained constant, i.e., the data obtained in the experiments were used, since the climatological model used does not have these variables for simulation. Two emission scenarios were evaluated based on the IPCC report: an optimistic one, named B2 and a pessimistic one, named A2. Scenario A2 is characterized by a world that operates independently, self-sufficient nations, progressive increase in population and economic development oriented towards the region. Scenario B2 describes a planet where the emphasis is on local solutions for economic, social and environmental sustainability. It is a world with continued increase in the world population at a lower rate than in scenario A2.

The temperature and relative humidity data used in the simulations for future scenarios (B2 and 
A2) were the outputs of the PRECIS (Providing Regional Climates for Impact Studies) climatological model, which is based on the third generation of the Hadley Centre regional model (HadRM3). The regional model HadRM3 has a horizontal resolution of $50 \mathrm{~km}$ with 19 vertical levels (from the surface up to $30 \mathrm{~km}$ in the stratosphere) and four levels in the soil. Its spatial resolution is $0.44 \times 0.44^{\circ}$ (latitude $\mathrm{x}$ longitude), which corresponds to an approximate grid of $50 \times 50 \mathrm{~km}$. More details about the PRECIS system can be obtained in Jones et al. (2004).

The Kc values determined in the experiments were compared with those obtained in the evaluated scenarios of climate change (B2 and A2), in which the coefficients were adjusted for the conditions of climate change. Kc values for climate change conditions were adjusted according to the equation proposed by Allen et al. (2006) (Equation 7):

$$
\mathrm{Kc}_{\text {current }}=\mathrm{Kc}_{\mathrm{tab}+}\left[0.04\left(\mathrm{u}_{2}-2\right)-0.004\left(\mathrm{RH}_{\min }-45\right)\right](\mathrm{h} / 3)^{0.3}(7)
$$

where: $\mathrm{Kc}_{\text {current }}$ - crop coefficient in the climate change scenarios; $\mathrm{Kc}_{\mathrm{tab}}$ - crop coefficient obtained in experiments and adjusted; $\mathrm{u}_{2}$ - average wind speed of the stage at $2 \mathrm{~m}$ height, $\mathrm{m} \mathrm{s}^{-1} ; \mathrm{RH}_{\min }$ average minimum relative humidity during the stage, $\%$; and $\mathrm{h}$ - average plant height in the stage, $\mathrm{m}$.

As the model provides only average relative humidity data, a form of proportion was used to determine the maximum and minimum values of relative humidity, i.e., the same percentage of change simulated for the mean relative humidity was assigned to the maximum and minimum values of relative humidity, the same form used by Cavalcante Júnior et al. (2018). These data were necessary for the ETo simulations and Kc adjustment.

The Kc values obtained in the experiments, for stages I, II, III and IV, respectively, were 0.24 , $074,1.10$ and 0.73 for the cultivar Mickylee and $0.15,0.90,1.52$ and 0.78 for Quetzali.

With the Kc values obtained during the cultivation periods, properly adjusted and with the new ETo values calculated for the optimistic (B2) and pessimistic (A2) scenarios, a new ETc was generated and comparison was performed between the water need of the crop under the current climatic conditions and the water needs for the two climate scenarios evaluated (B2 and A2).

\section{RESULTS AND DISCUSSION}

The optimistic (B2) and pessimistic (A2) scenarios resulted in air temperature increments on the order of 3.0 and $5.2{ }^{\circ} \mathrm{C}$ for mean temperature, 3.9 and $6.8{ }^{\circ} \mathrm{C}$ for maximum temperature and 2.1 and $3.8{ }^{\circ} \mathrm{C}$ for minimum temperature, respectively, for the year 2100 . These values refer to the average of the two watermelon cultivars along their growing periods (Table 1).

Table 1. Average values of mean (Tmean), maximum (Tmax) and minimum (Tmin) air temperatures $\left({ }^{\circ} \mathrm{C}\right)$ along the cultivation period of watermelon (cultivars Mickylee and Quetzali) in climate change scenarios in Mossoró, Rio Grande do Norte, Brazil.

\begin{tabular}{|c|c|c|c|c|c|c|c|c|c|}
\hline \multirow{3}{*}{ Period } & \multicolumn{9}{|c|}{ Climate change scenarios } \\
\hline & \multicolumn{3}{|c|}{ Current } & \multicolumn{3}{|c|}{ B2 } & \multicolumn{3}{|c|}{$\mathrm{A} 2$} \\
\hline & Tmean & Tmax & Tmin & Tmean & Tmax & Tmin & Tmean & Tmax & Tmin \\
\hline 1 & 27.0 & 32.9 & 23.3 & 30.9 & 38.0 & 26.0 & 34.5 & 42.9 & 28.4 \\
\hline 2 & 26.1 & 31.9 & 23.2 & 28.2 & 34.6 & 24.8 & 29.1 & 35.5 & 25.7 \\
\hline Mean & 26.6 & 32.4 & 23.3 & 29.6 & 36.3 & 25.4 & 31.8 & 39.2 & 27.1 \\
\hline
\end{tabular}

1 = February to April/2006 (Mickylee cultivar); 2 = September to November/2009 (Quetzali cultivar); Current: Current climate scenario; B2: Optimistic climate scenario for the year 2100; A2: Pessimistic climate scenario for the year 2100.

The lower and upper basal temperatures of the watermelon crop are 11 and $35^{\circ} \mathrm{C}$, i.e., this temperature range is considered satisfactory for its development (REZENDE; DIAS; COSTA, 2010). Because of this, the abrupt increases in the maximum air temperature of scenarios $\mathrm{B} 2$ and $\mathrm{A} 2$, in which maximum temperatures reach levels above the upper basal temperature, can interfere in the growth and development of watermelon cultivars, affecting their phenology, internode elongation, leaf expansion, production and partition of assimilates in different parts, and trigger the abortion of flowers, hence causing direct impacts on production (SILVA;
SILVA; AZEVEDO, 2012). Under high air temperature, above $35{ }^{\circ} \mathrm{C}$, the formation of male flowers in watermelon is stimulated. In addition, the association of high temperatures and winds causes a high rate of transpiration and increases internal pressure in fruits, causing the rind to break at the weakest points, thus affecting fruit yield and quality (REZENDE; DIAS; COSTA, 2010).

The relative humidity in the optimistic (B2) and pessimistic (A2) scenarios resulted in values lower than those in the current climatic situation, with reductions of 4.8 and $8.3 \%$ in the average relative humidity, respectively, for the year 2100 , 
and values refer to the average of the two cultivars, during their respective cultivation periods (Table 2). According to Rezende, Dias and Costa (2010), the ideal relative humidity range for watermelon cultivation is between 60 and $80 \%$. Thus, despite the reductions observed during the two periods of cultivation, it was found that relative humidity will be within the limits considered ideal for crop development, according to the average and maximum values for each period.

Table 2. Average values of mean (RHmean), maximum (RHmax) and minimum (RHmin) relative humidity (\%) along the cultivation period of watermelon (cultivars Mickylee and Quetzali) in climate change scenarios in Mossoró, Rio Grande do Norte, Brazil.

\begin{tabular}{|c|c|c|c|c|c|c|c|c|c|}
\hline \multicolumn{10}{|c|}{ Climate change scenarios } \\
\hline \multirow{2}{*}{ Period } & \multicolumn{3}{|c|}{ Current } & \multicolumn{3}{|c|}{ B2 } & \multicolumn{3}{|c|}{$\mathrm{A} 2$} \\
\hline & RHmean & RHmax & RHmin & RHmean & RHmax & RHmin & RHmean & RHmax & RHmin \\
\hline 1 & 75.9 & 90.7 & 47.5 & 68.5 & 83.3 & 40.0 & 62.4 & 77.2 & 34.0 \\
\hline 2 & 68.8 & 80.2 & 41.9 & 66.7 & 78.0 & 39.8 & 65.7 & 77.1 & 38.8 \\
\hline Mean & 72.4 & 85.5 & 44.7 & 67.6 & 80.7 & 39.9 & 64.1 & 77.2 & 36.4 \\
\hline
\end{tabular}

1 = February to April/2006 (Mickylee cultivar); 2 = September to November/2009 (Quetzali cultivar); Current: Current climate scenario; B2: Optimistic climate scenario for the year 2100; A2: Pessimistic climate scenario for the year 2100.

The accumulated degree days for the watermelons to reach physiological maturity were $1,328.1{ }^{\circ} \mathrm{C}$ for the cultivar Mickylee and $1,043.4{ }^{\circ} \mathrm{C}$ for the cultivar Quetzali, obtained at 78 and 63 days, respectively, for the current climatic scenario (Table 3).

Table 3. Accumulated degree days per stage (ADD) and average duration of phenological stages of watermelon cultivars in climate change scenarios, in the municipality of Mossoró, Rio Grande do Norte, Brazil.

\begin{tabular}{|c|c|c|c|c|c|c|c|c|}
\hline \multirow{3}{*}{$\begin{array}{l}\text { Watermelon cultivars } \\
\text { Stages }\end{array}$} & \multicolumn{4}{|c|}{ Mickylee cultivar } & \multicolumn{4}{|c|}{ Quetzali cultivar } \\
\hline & \multirow{2}{*}{$\begin{array}{l}\text { ADD } \\
\left({ }^{\circ} \mathrm{C}\right)\end{array}$} & \multicolumn{3}{|c|}{ Cycle duration (days) } & \multirow{2}{*}{$\begin{array}{c}\mathrm{ADD} \\
\left({ }^{\circ} \mathrm{C}\right)\end{array}$} & \multicolumn{3}{|c|}{ Cycle duration (days) } \\
\hline & & Current & $\mathrm{B} 2$ & $\mathrm{~A} 2$ & & Current & $\mathrm{B} 2$ & $\mathrm{~A} 2$ \\
\hline I - Initial & 301.6 & 17 & 15 & 13 & 262.0 & 16 & 15 & 15 \\
\hline II - Growth & 306.5 & 18 & 16 & 14 & 260.5 & 16 & 14 & 14 \\
\hline III - Intermediate & 389.3 & 23 & 19 & 16 & 338.2 & 20 & 19 & 18 \\
\hline IV - Final & 330.7 & 20 & 17 & 14 & 182.7 & 11 & 10 & 9 \\
\hline Total & $1,328.1$ & 78 & 67 & 57 & $1,043.4$ & 63 & 58 & 56 \\
\hline
\end{tabular}

Current: Current climate scenario; B2: Optimistic climate scenario for the year 2100; A2: Pessimistic climate scenario for the year 2100 .

For the cultivar Mickylee, in the optimistic scenario (B2), a reduction in crop cycle of 11 days $(14.1 \%)$ was observed compared to the current climatic scenario, being 2 days in the initial stage, 2 days in the growth stage, 4 days in the intermediate stage and 3 days in the final stage. With the increase in air temperature, for the pessimistic scenario (A2) there was a reduction of 21 days $(26.9 \%)$ in the crop, being 4 days in the initial stage, 4 days in the growth stage, 7 days in the intermediate stage and 6 days in the final stage (Table 3).

For the cultivar Quetzali, it was verified that with the increase in air temperature, for the optimistic scenario (B2) there was a reduction of 5 days $(7.9 \%)$ in the crop cycle, being 1 day in the initial stage, 2 days in the growth stage, 1 day in the intermediate stage and 1 day in the final stage. For the pessimistic scenario (A2), a greater reduction was observed in the crop cycle, equal to 7 days $(11.1 \%)$, being 1 day in the initial stage, 2 days in the growth stage, 2 days in the intermediate stage and 2 days in the final stage (Table 3 ).

Thus, climate change had greater impacts on the Mickylee cultivar cycle, with reductions of 21 days in the pessimistic scenario (A2), while the reduction in the Quetzali cultivar cycle was 7 days, compared to the current climatic scenario, which may be related to the longer cycle of the Mickylee cultivar (Table 3 ). It is also verified that the greatest reductions in the Mickylee cultivar cycle occur in the intermediate and final stages, with duration reductions of 7 and 6 days, respectively. Similar reductions occur for the cultivar Quetzali in the growth, intermediate and final stages, with reductions of 2 days in each stage. The greatest reductions in the intermediate and final stages 
observed for the Mickylee cultivar may pose more risk to its fruit production and quality, and the reproductive stages are the most sensitive to the future climate change scenario.

The increment in air temperature increases the speed of plant metabolic processes (LIU; TAO, 2013). This occurs because the production cycle of plants depends on the accumulated degree days, which are directly influenced by the increase in air temperature (BEZERRA et al., 2015). The impacts of climate change on the reduction in plant cycle have been observed in other crops of agricultural importance, such as cowpea (CAVALCANTE JUNIOR et al., 2016), soybean (SOUZA et al., 2018) and corn (CAVALCANTE JUNIOR et al., 2018). This occurs because the future projections for climate in the region have higher temperatures, around 3 to $5{ }^{\circ} \mathrm{C}$ for the optimistic scenario (B2) and 4 to $8{ }^{\circ} \mathrm{C}$ for the pessimistic scenario (A2) (JUSTINO et al., 2013).

When comparing the $\mathrm{Kc}$ values obtained along the experiments, it was observed that in the initial stage of cultivation the Kc obtained for the Mickylee cultivar was much higher than that of the Quetzali cultivar, which can be explained by the non -use of mulch in the cultivation of the Mickylee cultivar, which favored a greater loss of water by evaporation. In the other phenological stages, the Kc values obtained for the Quetzali cultivar were higher than those obtained for Mickylee, which can be explained by the greater vegetative vigor of Quetzali (Table 4).

The Kc values of the watermelon cultivars were altered as a function of the future climate changes simulated in temperature and relative humidity. For the Mickylee cultivar, there were reductions only in $\mathrm{Kc}$ values of the initial stage (0.05 and -0.07$)$ for $\mathrm{B} 2$ and $\mathrm{A} 2$ scenarios and in the growth stage (-0.02) for the A2 scenario, compared to the current scenario, respectively. There were increments in $\mathrm{Kc}$ in the intermediate $(+0.03$ and $+0.06)$ and final $(+0.04$ and +0.07$)$ stages for scenarios B2 and A2, compared to the current scenario, respectively. For the Quetzali cultivar, in scenario $\mathrm{B} 2$, there was a reduction in the $\mathrm{Kc}$ of the initial $(-0.01$ and -0.01$)$ and growth $(-0.13$ and -0.12$)$ stages and increments in the $\mathrm{Kc}$ of the intermediate $(+0.02$ and +0.05$)$ and final $(+0.07$ and +0.09$)$ stages for scenario $\mathrm{B} 2$ and $\mathrm{A} 2$, compared to the current scenario, respectively (Table 4).

Table 4. Crop coefficients $(\mathrm{Kc})$ of watermelon cultivars in climate change scenarios, in the municipality of Mossoró, Rio Grande do Norte, Brazil.

\begin{tabular}{|c|c|c|c|c|c|c|}
\hline \multirow[t]{3}{*}{ Watermelon cultivars } & \multicolumn{3}{|c|}{ Mickylee cultivar } & \multicolumn{3}{|c|}{ Quetzali cultivar } \\
\hline & \multicolumn{3}{|c|}{$\mathrm{Kc}$} & \multicolumn{3}{|c|}{$\mathrm{Kc}$} \\
\hline & Current & B2 & $\mathrm{A} 2$ & Current & B2 & $\mathrm{A} 2$ \\
\hline I - Initial & 0.24 & 0.19 & 0.17 & 0.15 & 0.14 & 0.14 \\
\hline II - Growth & 0.74 & 0.74 & 0.72 & 0.90 & 0.77 & 0.78 \\
\hline III - Intermediate & 1.10 & 1.13 & 1.16 & 1.52 & 1.54 & 1.57 \\
\hline IV - Final & 0.73 & 0.77 & 0.80 & 0.78 & 0.85 & 0.87 \\
\hline
\end{tabular}

Current: Current climate scenario; B2: Optimistic climate scenario for the year 2100; A2: Pessimistic climate scenario for the year 2100

The changes in the Kc of the different phenological stages of the crop, according to Bernardo, Soares and Mantovani (2009), occur due to the local evapotranspiration demand and the sensitivity of the crop to soil water deficit. These indications show that the cultivars Mickylee and Quetzali are sensitive to variations in the optimistic (B2) and pessimistic (A2) scenarios in all stages of their reproductive cycle. However, in the pessimistic scenario (A2), the cultivar Mickylee undergoes greater changes in $\mathrm{Kc}$ in the initial, intermediate and final stages, while Quetzali will be more sensitive in the growth stage.

The ETc of the watermelon cultivar Mickylee in the optimistic scenario (B2) was reduced in the initial $(0.63 \mathrm{~mm} / \mathrm{stage})$ and intermediate $(0.26 \mathrm{~mm} /$ stage) stages and increased in the growth $(8.41 \mathrm{~mm} /$ stage) and final (10.47 mm/stage) stages, compared to the current scenario, while ETc in the pessimistic scenario (A2) was reduced in the initial $(3.65 \mathrm{~mm} /$ stage), growth (0.86 mm/stage) and intermediate $(0.43 \mathrm{~mm} / \mathrm{stage})$ stages and increased in the final stage $(20.81 \mathrm{~mm} /$ stage $)$, compared to the current scenario (Table 5). 
Table 5. Crop evapotranspiration (ETc) of watermelon cultivars in climate change scenarios in the municipality of Mossoró, Rio Grande do Norte, Brazil.

\begin{tabular}{|c|c|c|c|c|c|c|}
\hline \multirow[t]{3}{*}{ Watermelon cultivars } & \multicolumn{3}{|c|}{ Mickylee cultivar } & \multicolumn{3}{|c|}{ Quetzali cultivar } \\
\hline & \multicolumn{3}{|c|}{ ETc $(\mathrm{mm})$} & \multicolumn{3}{|c|}{$\operatorname{ETc}(\mathrm{mm})$} \\
\hline & Current & B2 & A2 & Current & B2 & $\mathrm{A} 2$ \\
\hline I - Initial & 17.56 & 16.93 & 13.91 & 15.40 & 14.85 & 15.10 \\
\hline II - Growth & 67.07 & 75.48 & 66.21 & 86.38 & 82.10 & 85.59 \\
\hline III - Intermediate & 110.19 & 109.93 & 109.76 & 196.06 & 201.39 & 201.92 \\
\hline IV - Final & 51.19 & 61.66 & 72.00 & 50.85 & 47.50 & 46.39 \\
\hline Total & 246.01 & 263.99 & 261.88 & 348.69 & 345.85 & 349.00 \\
\hline Daily Mean & 3.15 & 3.94 & 4.62 & 5.53 & 5.96 & 6.23 \\
\hline
\end{tabular}

Current: Current climate scenario; B2: Optimistic climate scenario for the year 2100; A2: Pessimistic climate scenario for the year 2100 .

There were increments in the daily ETc for the two cultivars analyzed, being $25.1 \%$ and $46.7 \%$ for Mickylee and $7.8 \%$ and $12.7 \%$ for Quetzali, in scenarios $\mathrm{B} 2$ and $\mathrm{A} 2$, respectively. Therefore, there are greater increments for Mickylee than for Quetzali, which may be related to the greater increase in the total ETc of this cultivar, while the total ETc of Quetzali was little changed in the two scenarios evaluated, with greater increments in scenario A2, due to the greater increase in air temperature and greater reduction of relative humidity in this scenario, which increases local evapotranspiration demand.

For the cultivar Quetzali in the optimistic (B2) and pessimistic (A2) scenarios, reductions in ETc on the order of $0.55 \mathrm{~mm}$ and $0.30 \mathrm{~mm}$ were observed in the initial stages, of $4.28 \mathrm{~mm}$ and 0.79 $\mathrm{mm}$ in the growth stage and of $3.35 \mathrm{~mm}$ and 4.46 $\mathrm{mm}$ in the final stage, respectively, compared to the current scenario. However, the ETc was increased by $5.33 \mathrm{~mm}$ and $5.86 \mathrm{~mm}$ in the intermediate stage in the optimistic (B2) and pessimistic (A2) scenarios, respectively, compared to the current scenario (Table $5)$.

The total ETc of the Mickylee cultivar was increased as a function of the changes in air temperature and relative humidity in the optimistic (B2) and pessimistic (A2) scenarios, on the order of $7.3 \%$ and $6.45 \%$, respectively. In the total ETc of the cultivar Quetzali, there was a $0.81 \%$ reduction only in the optimistic scenario (B2), and an $0.09 \%$ increase in the pessimistic scenario (A2), indicating that the variations in the $\mathrm{Kc}$ of the crop had little influence on ETc, when compared to the cultivar Mickylee (Tables 4 and 5), thus showing that the variety of longer cycle underwent greater changes in phenology and gas exchange compared to that of shorter cycle.

When evaluating the A2 and B2 scenarios projected by IPCC in northeastern Spain, Savé et al. (2012) found that water requirement tends to increase between 40 and $250 \%$ depending on the crop analyzed in the study (corn, alfalfa and apple), due to the variations that should occur in ETc and crop phenology, caused by reduced precipitation and increased air temperature. According to Cavalcante Junior et al. (2018), these studies provide valuable information on possible impacts and guidelines of strategies for adaptations, through different agronomic management practices, since changes in the phenology and water demand of the crop implies changes in cultural practices and in irrigation management.

Thus, the changes in the water demand of the watermelon crop are indicative of the need for adapting its irrigation management to future scenarios, aiming to supply the higher daily water demand for the plant because, with the reduced cycle, the period for recovering from water deficit is shorter, which may lead to greater risks to production.

\section{CONCLUSIONS}

There was a reduction in relative air humidity and an increase in air temperature for the watermelon cultivars, in the two scenarios of climate change evaluated (B2 and A2).

There were reductions of 14.1 and $26.9 \%$ in the duration of the development cycle of the cultivar Mickylee and 7.9 and $11.1 \%$ for the cultivar Quetzali, considering the optimistic and pessimistic scenarios, respectively, compared to the current climatic scenario.

The cultivar Mickylee is more sensitive to climate change in the growth, intermediate and final stages, hence being more susceptible to production losses than the cultivar Quetzali.

Future climate changes will increase watermelon $\mathrm{Kc}$, for the conditions under which the present study was conducted, increasing daily 
evapotranspiration and total evapotranspiration, especially for the cultivar Mickylee.

\section{REFERENCES}

ALLEN, R. G. et al. Evapotranspiration del cultivo: guias para la determinación de los requerimientos de agua de los cultivos. Roma: FAO, 2006, 298 p.

ALVARES, C. A. et al. Köppen's climate classification map for Brazil. Meteorologische Zeitschrift, 22: 711728, 2014.

BEDDINGTON, J. R. et al. What next for agriculture after Durban? Science, 335: 289-290, 2012.

BERNARDO, S.; SOARES, A. A.; MANTOVANI, E. C. Manual de irrigação. 8. ed. Viçosa, MG: UFV, 2009. $625 \mathrm{p}$.

BEZERRA, S. A. F. et al. Demanda hídrica bruta da palma forrageira em cenários futuros de mudanças climáticas no Estado de Pernambuco. Revista Brasileira de Geografia Física, 8: 1628-1643, 2015.

CARMO, I. L. G. S. et al. Desempenho agronômico de cultivares de melancia no cerrado de Boa Vista, Roraima. Revista Agro@mbiente On-line, 9: 268274, 2015.

CAVALCANTE JÚNIOR, E. G. et al. Development and water requirements of cowpea under climate change conditions in the Brazilian semi-arid region. Revista Brasileira de Engenharia Agrícola e Ambiental, 20: 783-788, 2016.

CAVALCANTE JÚNIOR, E. G. et al. Necessidade hídrica da cultura do milho influenciada pelas mudanças climáticas no semiárido nordestino. Revista Brasileira de Milho e Sorgo, 17: 251-262, 2018.

CHAVES, P. P. N., FERREIRA, T. A., ALVES, A. F. Caracterização físico-química e sensorial de famílias de melancia tipo crimson sweet selecionadas para reação de resistência a potyvirus. Revista Verde de Agroecologia e Desenvolvimento Sustentável, 8: 120-125, 2013.

COSTA, F. G. B. et al. Crescimento da melancia e monitoramento da salinidade do solo com TDR sob irrigação com águas de diferentes salinidades. Irriga, 17: 327-336, 2012.

COSTA, A. R. F. C. et al. Produção e qualidade de melancia cultivada com água de diferentes salinidades e doses de nitrogênio. Revista Brasileira de Engenharia Agrícola e Ambiental, 17: 947-954,
2013.

DALASTRA, G. M.; ECHER, M. M.; HACHMANN, T. L. Desempenho de cultivares de melão, em função do número de frutos por planta. Journal of Agronomic Sciences, 4: 26-41, 2015.

DINIZ, M. T. M.; PEREIRA, V. H. C. Climatologia do estado do Rio Grande do Norte, Brasil: sistemas atmosféricos atuantes e mapeamento de tipos de clima. Boletim Goiano de Geografia, 35: 488-506, 2015 .

EMPRESA BRASILEIRA DE PESQUISA AGROPECUÁRIA - EMBRAPA. Sistema brasileiro de classificação de solo. Brasília, DF: EMBRAPA, 1999. 412 p.

FIGUEIRÊDO, V. B. et al. Evapotranspiração da cultura da melancia irrigada com água de diferentes salinidades. Engenharia Agrícola, 29: 231-240, 2009.

JONES, R. G. et al. Generating high resolution climate change scenarios using PRECIS. Exeter, Uk: Met Office Hadley Centre, 2004. 40 p.

JUSTINO, F. et al. Mean and interannual variability of mayze and soybean in Brazil under global warming conditions. American Journal of Climate Change, 2: 237-253, 2013.

KASTNER, T. et al. Global changes in diets and the consequences for land requirements for food. Proceedings of the National Academy of Sciences, 109: 6868-6872, 2012.

LIU, Y.; TAO, F. Probabilistic change of wheat productivity and water use in China for Global mean temperature change of 1,2 and $3{ }^{\circ} \mathrm{C}$. Journal of Applied Meteorology and Climatology, 52: 114129, 2013

NELSON, G. C. et al. Climate change effects on agriculture: economic responses to biophysical shocks. Proceedings of the National Academy of Sciences, 111: 3274-3279, 2014.

NUNES, F. C. A. P. et al. Viabilidade econômica do cultivo irrigado da melancia no estado do Piauí. Irriga, 22: 101-114, 2017.

OMETTO, J. C. Bioclimatologia vegetal. 1. ed. São Paulo, SP: Agronômica Ceres, 1981. 440 p.

RENATO, N. S. et al. Influência dos métodos para cálculo de graus-dia em condições de aumento de temperatura para as culturas de milho e feijão. Revista Brasileira de Meteorologia, 28: 382-388, 2013. 
REZENDE, G. M.; DIAS, R.C. S.; COSTA, N. D. Sistema de Produção de Melancia. 6. Versão eletrônica, 2010. Disponível em: <https:// sistemasdeproducao.cnptia.embrapa.br/FontesHTML/ Melancia/SistemaProducaoMelancia/clima.htm>. Acesso em: 03 set. 2019.

SAVÉ, R. et al. Potential changes in irrigation requirements and phenology of maize, apple trees and alfalfa under global change conditions in Fluvià watershed during XXIst century: Results from a modeling approximation to watershed-level water balance. Agricultural Water Management, 114: 7887, 2012.

SCHMIDT, D. M.; LIMA, K. C.; JESUS, E. S. Variabilidade Climática da Disponibilidade Hídrica na Região Semiárida do Estado do Rio Grande do Norte. Anuário do Instituto de Geociências, 41, 483-491, 2018.

SCHEMBERGUE, A. et al. Sistemas agroflorestais como estratégia de adaptação aos desafios das mudanças climáticas no Brasil. Revista de Economia Sociologia Rural, 55: 9-30, 2017.

SILVA, L. D. B.; FOLEGATTI, M. V.; NOVA, N. A. V. Evapotranspiração do capim tanzânia obtida pelo método de razão de Bowen e lisímetro de pesagem. Engenharia Agrícola, 25: 705-712, 2005.

SILVA, M. T.; SILVA, V. P. R.; AZEVEDO, P. V. O cultivo do algodão herbáceo no sistema de sequeiro no Nordeste do Brasil, no cenário de mudanças climática. Revista Brasileira de Engenharia Agrícola e Ambiental, 16: 80-91, 2012.

SOUZA, P. J. O. P. et al. Impactos das mudanças climáticas na cultura da soja no nordeste do estado do Pará. Revista Brasileira de Agricultura Irrigada, 12: 2454-2467, 2018. 